\title{
A-kinase anchoring proteins and neuronal signaling mechanisms
}

\author{
Graeme K. Carnegie and John D. Scott ${ }^{1}$ \\ Howard Hughes Medical Institute, Vollum Institute, Oregon Health and Sciences University, Portland, Oregon 97201, USA
}

The rapid and reversible phosphorylation of proteins catalyzed by protein kinases and protein phosphatases is a well recognized mechanism of regulation in cells. This bidirectional process is a highly flexible method of influencing cellular activity in response to a variety of incoming stimuli. A physiological role for protein phosphorylation was first identified about 50 years ago while investigating the regulation of glycogen metabolism (Fischer and Krebs 1955; Sutherland 1972). In fact, many aspects of gene regulation; cell cycle control, transport, and secretion; actin remodeling; and cell adhesion are controlled by this mechanism (Krebs 1985; Hunter 1995; Pawson and Scott 1997; Cohen 2000; Goodman and Smolik 2000; Pawson and Nash 2000). The utility of protein phosphorylation as the predominant form of covalent modification of proteins in vivo is exemplified by the finding that $\sim 30 \%$ of intracellular proteins are phosphoproteins (Hunter 1987). Not surprisingly, the breakdown in signal transduction may be the cause or consequence of many diseases, including cancer, diabetes, arthritis, and Alzheimer's (Cohen 1999).

Most signaling pathways are composed of common elements. The initial signal is transduced through a receptor at the plasma membrane (such as a G-protein coupled receptor, or a receptor tyrosine kinase or phosphatase), which results in activation of the receptor or the mobilization of receptor-associated proteins to generate some form of intracellular message. This signal is then directed throughout the cell either by the diffusion of a small soluble second messenger or the translocation of an activated enzyme. At a molecular level, phosphorylation mediates the regulation of enzymatic activities by causing allosteric conformational changes, or by directly enhancing or blocking access to enzyme catalytic sites (Johnson and Barford 1990; Barford et al. 1991; Johnson and O'Reilly 1996). More recently it has been realized that an essential feature of signaling by protein phosphorylation is the modulation of protein-protein interactions. These are mediated by a growing number of protein interaction modules including WW, SH2, PTB, 143-3, WD-40, FHA, and FF domains that may associate

${ }^{1}$ Corresponding author.

E-MAIL scott@ohsu.edu; FAX (503) 494-0519.

Article and publication are at http://www.genesdev.org/cgi/doi/10.1101/ gad.1095803. with their binding partners in a phosphorylation-dependent manner (Cantley et al. 1991; Pawson and Gish 1992; Pawson 1995). These protein-protein interactions generate molecular networks that drive intracellular signaling events. This fascinating topic was recently the subject of several excellent reviews (Burack and Shaw 2000; Hunter 2000; Jordan et al. 2000; Pawson and Nash 2000; Sudol and Hunter 2000). In this article we emphasize how the subcellular location of protein kinases and phosphatases provides a means to restrict where and when phosphorylation events occur. In particular, we discuss the compartmentalization of the cAMP-dependent protein kinase (protein kinase A; PKA) through its association with A-kinase anchoring proteins (AKAPs).

\section{cAMP-dependent signaling mechanisms}

The second messenger cAMP was identified in 1957 as a factor that stimulates glycogen phosphorylase (Rall et al. 1957; Rall and Sutherland 1958). However, this discovery as well as the development of the second messenger concept was not fully appreciated until a cAMP-dependent protein kinase was characterized over a decade later (Walsh et al. 1968). Ever since this initial discovery, an intense global research effort has elucidated many molecular and cellular actions of cAMP. Engagement of transmembrane receptors and the recruitment of intermediary $\mathrm{G}$ proteins activate adenylyl cyclases on the inner face of the plasma membrane (Tang and Gilman 1992). This cascade of events triggers an elevation of cAMP in certain intracellular compartments (Barsony and Marks 1990; Adams et al. 1991; Bacskai et al. 1993). Although cAMP modulates the activities of molecules such as cyclic-nucleotide gated ion channels (Kaupp and Seifert 2002), guanine nucleotide exchange factors (GEFs; de Rooij et al. 2000), and cyclic-nucleotide phosphodiesterases (Houslay 2001), the predominant intracellular receptor for this second messenger is the cAMPdependent protein kinase (PKA).

Most cell types express multiple cAMP-dependent protein kinase forms. The PKA holoenzyme is a tetramer composed of two catalytic (C) subunits that are held in an inactive state by association with a regulatory $(\mathrm{R})$ subunit dimer (Corbin et al. 1973; Corbin and Keely 1977; Potter et al. 1978; Potter and Taylor 1979). The catalytic subunits (C) are expressed from three different genes; $\mathrm{C} \alpha$, 
$C \beta$, and $C \gamma$, whereas the regulatory subunits $(R)$ are expressed from four different genes; RI $\alpha, \mathrm{RI} \beta, \mathrm{RII} \alpha$, and RII $\beta$ (Lee et al. 1983; Scott et al. 1987; Chrivia et al. 1988). The $\mathrm{R}$ subunit is a modular protein containing an $\mathrm{NH}_{2}$-terminal homo-dimerization domain, a pseudosubstrate/autophosphorylation site that serves as the principal site of contact for the $\mathrm{C}$ subunit, and two cAMPbinding sites. Binding of cAMP to the $\mathrm{R}$ subunits relieves the autoinhibitory contact, causing the $\mathrm{C}$ subunits to dissociate and allowing phosphorylation of substrates (Wang et al. 1991; Gibbs et al. 1992). Two subtypes of the PKA holoenzyme can be formed. The type I PKA /composed of RI dimers) is thought to be predominantly cytoplasmic and is most highly expressed in the immune system, whereas type II PKA (composed of RII dimers) associates with specific cellular structures and organelles and is abundant in the heart and brain (Scott 1991).

One remaining question in PKA signaling is how this "broad spectrum" kinase can be implicated in the specific regulation of so many physiological processes. This is compounded by evidence that multiple agonists that engage a ubiquitous cAMP synthesis pathway initiate specific PKA phosphorylation events (Livesey et al. 1982). Accordingly, the mechanism by which PKA distinguishes between its substrates is a topic of intense investigation. This is particularly true in the brain, where PKA substrates such as ligand-gated and voltagegated ion channels are clustered together at synapses, yet changes in the phosphorylation state of either substrate cause distinct changes in synaptic plasticity (Brandon et al. 1995, 1997; Malenka and Nicoll 1999; Kind and Neumann 2001; Malinow and Malenka 2002; Sheng and Kim 2002). One explanation for this phenomenon is that compartment-specific pools of PKA are activated in close proximity to these channels. However, this can only occur if there is a means to selectively manipulate subcellular pools of cAMP. Accordingly, it has been proposed that a balance of adenylyl cyclase and phosphodiesterase activities leads to establishment of intracellular gradients of cAMP (Dell'Acqua and Scott 1997). Within these theoretical "nano-compartments", the activation state of PKA is believed to mirror the ebb and flow of second messenger levels (Beavo and Brunton 2002; Zaccolo and Pozzan 2002). In order to maintain PKA at these sites, "organizing" proteins called AKAPs exist to restrict the diffusion of the kinase and place the enzyme close to certain substrates (Rubin 1994; Colledge and Scott 1999; Skalhegg and Tasken 2000; Kapiloff 2002; Smith and Scott 2002). This review concentrates on the role of AKAPs as molecular mediators of PKA signaling specificity in the brain.

\section{The AKAP model}

The first AKAPs were identified as proteins that copurified with the type II PKA holoenzyme (Theurkauf and Vallee 1982; Bregman et al. 1989). Neuronal proteins, such as MAP2 and p75 (now known as AKAP75) were initially designated "RII-binding proteins" on the basis of their ability to remain tightly associated with the type
II $\mathrm{R}$ subunits during affinity purification on cAMPsepharose (Theurkauf and Vallee 1982; Bregman et al. 1989). The development of a modified Western blot procedure called the RII-overlay led to the identification of additional AKAPs in the brain and most other tissues (Lohmann et al. 1984; Carr and Scott 1992). This technique was subsequently adapted for use in an interaction cloning strategy where radiolabeled RII was used as a probe to screen cDNA expression libraries (Bregman et al. 1991; Carr et al. 1992a,b; Coghlan et al. 1994). Using this and related techniques, upwards of 30 AKAPs have been identified (Colledge and Scott 1999; Bauman and Scott 2002). Most AKAPs share three common properties (Fig. 1): (1) an R subunit-binding sequence, (2) unique localization signals that target the PKA/AKAP complex to membranes, organelles, and subcellular environments, and (3) additional enzyme-binding sites that permit the formation of multiprotein signaling complexes. Each of these properties is discussed below.

\section{Common PKA anchoring domains}

Most AKAPs contain a recognizable sequence that forms a binding site for the $\mathrm{R}$ subunits. This motif was first identified in the human thyroid anchoring protein, AKAP-lbc, where a 24-residue peptide called Ht31 was generated that bound RII with nanomolar affinity /Carr et al. 1991, 1992a). The Ht31 sequence is predicted to form an amphipathic helix, and structural studies indicate that this region slots into a binding pocket formed by the N-terminal regions of each RII protomer (Newlon et al. 1997, 1999, 2001). Cellular delivery of this peptide has become a standard means to delineate a role for AKAPs in the coordination of cAMP-responsive events by antagonizing PKA anchoring inside cells (Rosenmund et al. 1994; Lester et al. 1997; Vijayaraghavan et al. 1997; Feliciello et al. 2001; Moita et al. 2002; Tavalin et al. 2002). A consensus PKA anchoring motif called "AKAPIS" was recently derived from a comprehensive analysis

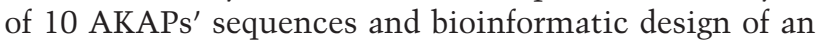
optimal RII-binding peptide. This 17-residue peptide binds RII with subnanomolar affinity and disrupts PKA anchoring inside cells (Alto et al. 2003). The AKAP-IS sequence has also been used as a motif to screen genomes for potential AKAPs.

Although AKAPs were initially thought to interact only with the type II PKA holoenzyme, there is now ample evidence showing that many anchoring proteins also target the type I kinase (Burton et al. 1997; Banky et al. 2000; Herberg et al. 2000). Two-hybrid screening and affinity purification techniques have identified dualfunction anchoring proteins that can interact with RI or RII and, in a few instances, RI-selective AKAPs have been reported (Angelo and Rubin 1998; Kussel-Andermann et al. 2000; Li et al. 2001). It would appear that RI anchoring also proceeds through the amphipathic helix, although there may be specific determinants that contribute to the compartmentalization of the type I PKA holoenzyme. In fact, substitution of aliphatic side chains in the hydrophobic face of the Ht31 helix increases af- 


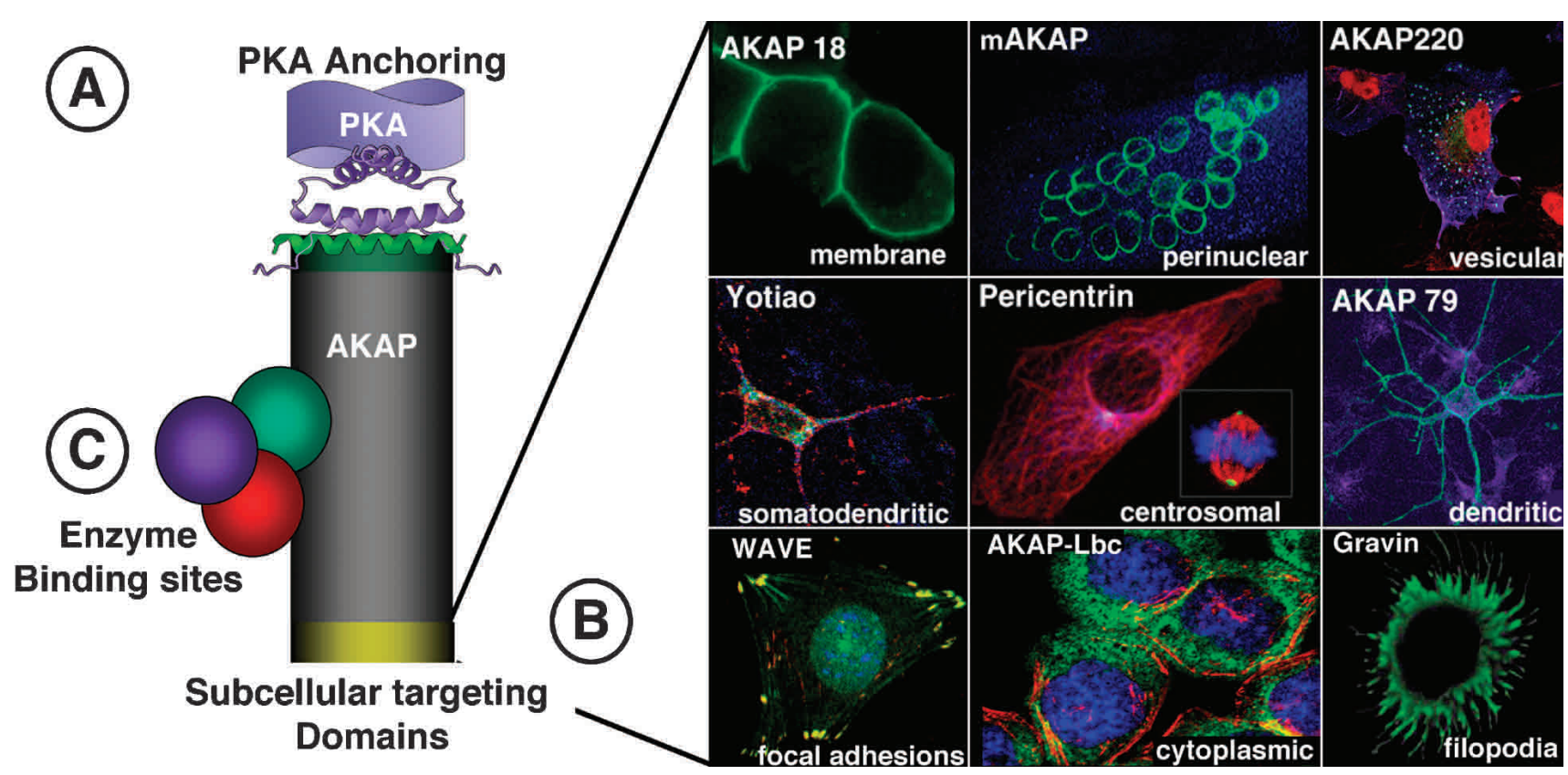

Figure 1. The AKAP model. At least three distinct functional domains are found on all AKAPs. (A) AKAPs contain a PKA-RII/RIbinding domain that mediates a high-affinity interaction with the PKA holoenzyme. $(B)$ AKAPs have a unique targeting domain that is required for the localization of PKA to distinct regions of the cell. The name and location of each compartment-specific AKAP are indicated in each panel. $(C)$ AKAPs are modular proteins that contain many protein-protein interaction motifs. Additional protein kinases are found associated with AKAPs for the purpose of integrating the cAMP second-messenger system with other secondmessenger systems. Protein phosphatases are localized to AKAPs for the regulation of many bidirectional phospho-transfer reactions. Phosphodiesterases may control the levels of local cAMP gradients by regulating the breakdown of cAMP.

finity for RI (Miki and Eddy 1999). In contrast, anchoring proteins such as D-AKAP-1/sAKAP84/149 and D-AKAP-2 exhibit less selectivity for either $\mathrm{R}$ subunit and have been designated as dual-function AKAPs (Huang et al. 1997a,b). Interestingly, recent evidence suggests that a single nucleotide polymorphism (SNP) that is identified in the aging human population causes a valine to isoleucine mutation in the anchoring helix of D-AKAP-2. This mutation increases RI-binding affinity threefold but has no effect on the RII/D-AKAP-2 interaction (Kammerer et al. 2003). In an accompanying paper, those same authors used peptide array technologies to generate a high-affinity binding peptide with a 100 fold preference for RI (Burns-Hamuro et al. 2003). Thus it seems likely that reagents will soon be on hand to permit the selective uncoupling of the type I and type II PKA holoenzymes inside cells.

\section{Unique targeting regions}

Compartmentalization of PKA-AKAP complexes involves specialized targeting regions on each anchoring protein that participate in protein-lipid or protein-protein interactions. An emerging principle is that proteinlipid interactions target the AKAP/PKA complex to the correct subcellular environment, while additional protein-protein interactions precisely orient the kinase toward its substrates. For example, myristoylation and palmitoylation signals guide the membrane tethering of AKAP15/18 in close proximity of PKA substrates such as calcium channels and sodium channels (Fraser et al. 1998; Gray et al. 1998). Yet AKAP15/18 may also be cross-linked to the $\alpha_{1}$ subunit of the L-type $\mathrm{Ca}^{2+}$ channel via a modified leucine zipper motif. Mutation of this targeting sequence on AKAP15/18 prevents kinase anchoring and voltage-dependent potentiation of $\mathrm{Ca}^{2+}$ channel activity (Hulme et al. 2002). A parallel mechanism may be in place to precisely orient AKAP15/18 toward neuronal sodium channels, which are also regulated by an anchored pool of PKA. Lipid-binding and protein interaction domains act synergistically to target another anchoring protein, AKAP79/150, to a range of synaptic substrates (Dell'Acqua et al. 1998). Repeat sequences that bind negatively charged phospholipids orient AKAP79/150 to the inner face of synaptic plasma membranes, whereas this anchoring protein is selectively coupled to distinct substrates such as the AMPAtype glutamate receptor ion channels, calcium channels, or potassium channels through specific protein-protein interactions (Colledge et al. 2000; Dodge and Scott 2000). The mechanism and functional ramifications of AKAP79/150 targeting are discussed in detail below.

In some cases, targeting of AKAP complexes to substrates only involves protein-protein interactions. MAP2 anchors PKA to microtubules through a C-terminal repeat sequence. Phosphorylation of three PKA sites within each tubulin-binding repeat destabilizes interaction with microtubules (Itoh et al. 1997). Genetic disruption of the MAP2 gene in mice causes a redistribution of the PKA holoenzyme in neurons that limits certain 
cAMP-responsive phosphorylation events and causes a reduction in microtubule density and dendritic length (Harada et al. 2002). One substrate is the L-type calcium channel, which was reported to be present in a macromolecular complex with MAP2, the PKA holoenzyme, and the $\beta 2$-andrenergic receptor (Davare et al. 1999). However, cAMP signaling to the L-type calcium channel is maintained in MAP2 knockout mice by compensatory recruitment of anchoring proteins such as AKAP79/150 and AKAP15/18 that also functionally couple to the channel (Gao et al. 1997; Gray et al. 1997).

There are several instances where multiple AKAPs mediate targeting to the same organelle. Three anchoring proteins (D-AKAP-1/AKAP149, D-AKAP-2, and Rab32) anchor PKA at mitochondria (Huang et al. 1997a, 1999; Alto et al. 2002); two AKAPs (AKAP350-450/CGNAP and pericentrin) tether the kinase to centrosomes (Schmidt et al. 1999; Diviani et al. 2000), and Ezrin, WAVE-1, and AKAP-lbc tether PKA to distinct areas of the actin cytoskeleton (Dransfield et al. 1997a; Westphal et al. 2000; Diviani et al. 2001). Also, an unspecified number of anchoring proteins restrict kinase localization in sperm (Moss and Gerton 2001). One explanation for these apparent redundancies may be the need to always have a pool of anchored PKA at certain sites. Alternatively, each compartment-specific AKAP may direct the kinase to different subcompartments where specific substrates reside. This latter hypothesis implies that the compartmentalization of PKA could be a more subtle and organized process than was initially appreciated.

\section{Signaling complexes}

A most important feature of AKAPs is their ability to interact with several signaling proteins. By simultaneously tethering PKA with enzymes such as protein phosphatases, phosphodiesterases, G proteins, and other protein kinases, these multivalent anchoring proteins coordinate the assembly of signaling complexes that provide focal points for the integration and processing of distinct intracellular signals. The following sections review the role of AKAP signaling complexes in neuronal function.

\section{AKAP79/150}

The notion of multivalent anchoring proteins was first proposed for the AKAP79/150 family, a group of three structurally similar orthologs: human AKAP79, murine AKAP150, and bovine AKAP75. The first evidence for a scaffolding function came from a yeast two-hybrid screen using AKAP79 as the bait that isolated clones for the catalytic subunit of the protein phosphatase PP2B (calcineurin; Coghlan et al. 1995). This finding explained earlier biochemical evidence that PP2B copurified with PKA and an unidentified $75-\mathrm{kD}$ protein from bovine brain extracts (Sarkar et al. 1984). The PP2B-binding site has now been mapped to a region between residues 315 and 360 of AKAP79, and evidence for the assembly of a PKA-AKAP79-PP2B ternary complex in living cells was provided by fluorescence resonance energy transfer
(FRET; Dell'Acqua et al. 2002; Oliveria et al. 2003). These experiments demonstrate that PKA and PP2B are precisely targeted to the same intracellular locus. AKAP79/150 also interacts with the catalytic core of most protein kinase $\mathrm{C}(\mathrm{PKC})$ isoforms via a site within the first 75 residues of the anchoring protein (Klauck et al. 1996; Faux et al. 1999). This provides a mechanism to direct dormant PKC isoforms to postsynaptic membranes. Inhibition of the anchored kinase is relieved by binding of $\mathrm{Ca}^{2+} /$ calmodulin in a competitive manner, leading to liberation of active PKC at the postsynaptic densities (Faux and Scott 1997). Thus AKAP79/150 organizes two kinases and a phosphatase that respond to distinct combinations of second messenger signals at synaptic sites (Fig. 2). Each enzyme participates in the control of distinct phosphorylation events. PP2B opposes the modulation of hippocampal AMPA receptors by anchored PKA (Tavalin et al. 2002). AKAP79/150 has also been implicated in anchoring of PKA and PKC close to the inwardly rectifying potassium channel, Kir2.1 (Dart and Leyland 2001), the $\beta 2$ adrenergic receptor (Fraser et al. 2000; Cong et al. 2001), metabotropic glutamate receptors (mGluR5) in perirhinal cortex neurons (Cho et al. 2002), and GABA receptors at inhibitory synapses (Brandon et al. 2003).

Although phospholipid-binding domains tether AKAP79/150 to the synaptic membranes, more precise orientation of the signaling complex toward particular substrates is conferred by protein-protein interactions. For example, AKAP79/150 is recruited to heteromeric NMDA receptor clusters through interaction with the membrane-associated guanylyl kinase (MAGUK) PSD95 (Colledge et al. 2000). This prototypic synaptic adapter protein contains three PDZ domains, one of which binds to the C-terminal tail of the NMDA receptor, an SH3 domain, and a guanylyl kinase-like domain which interacts with AKAP79/150. Biochemical frac-

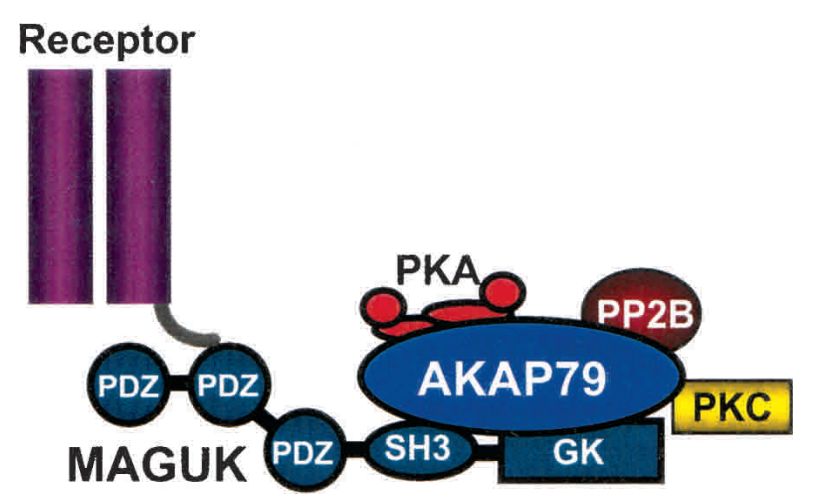

Figure 2. AKAP79 scaffold model. Generic illustration of the AKAP79 signaling complex. AKAP79 maintains a signaling scaffold of PKA, PKC, and PP2B, attached to the inner face of the neuron plasma membrane via association with negatively charged phospholipids. More precise orientation of the AKAP79 signaling complex can be mediated by interaction with a membrane-associated guanylyl kinase (MAGUK), which may act as a bridge to link anchored PKA to specific substrates, such as a receptor in the neuron plasma membrane. 
tionation, co-immunoprecipitation, and immunocytochemical labeling of cultured hippocampal neurons indicate that AKAP150 and PSD-95 are present at a majority of excitatory synapses (Colledge et al. 2000). In contrast, recruitment of AKAP79/150 to AMPA-type glutamate receptors is mediated via association with another MAGUK protein, SAP97, which acts as a protein bridge to link anchored PKA with a specific substrate, the glutamate receptor subtype GluR1 (Colledge et al. 2000). This elaborate molecular bridging facilitates the phosphorylation of Ser 845 in the cytoplasmic tail of GluR1, an important regulatory site on the channel that is modified during chemically induced long-term potentiation (LTP; Lee et al. 1998). Dephosphorylation of Ser 845 and attenuation of GluR1 channels are mediated by PP2B. In fact, peptide-mediated disruption of PP2BAKAP79/150 interaction prevents efficient dephosphorylation of the channel and suggests that tight coupling of the phosphatase with its substrate is necessary for modulation of channel activity (Tavalin et al. 2002).

Orientation of the AKAP79/150 signaling complex toward other synaptic substrates is achieved by different binding surfaces on the anchoring protein. The cytoplasmic tail of the KNCQ 2 potassium channel interacts directly with sites in the central portion of AKAP150. This provides a mechanism to precisely orient PKC to sites where it can efficiently phosphorylate Ser 534 and Ser 541 of the channel. Electrophysiological studies have shown that activation of PKC in superior cervical ganglion (SCG) neurons results in the phosphorylation and attenuation of KNCQ 2 channels. The introduction of protein fragments which disrupt the AKAP150-KNCQ 2 channel interaction uncouple this effect, suggesting that an intact macromolecular complex of the channel, anchoring protein, and PKC is required to efficiently attenuate the potassium channel (Hoshi et al. 2003). As the number of AKAP79/150 binding partners increases it is clear that a single anchoring protein can only interact with a subset of these proteins. Thus the postsynaptic environment is likely to contain an array of AKAP79/ 150 signaling complexes with unique compliments of proteins that are engaged in regulation of distinct substrates and molecular events.

\section{WAVE-1}

WAVE-1 (also known as Scar-1) is a member of the Wiskott-Aldrich syndrome protein (WASP) family (Machesky and Insall 1998, 1999; Machesky et al. 1999; Rohatgi et al. 1999). It is a scaffold protein that principally functions to relay signals from the small GTPase Rac to the Arp $2 / 3$ complex, a group of seven related proteins that function to nucleate actin polymerization and facilitate dendritic branching of actin filaments (Miki et al. 1998; Robinson et al. 2001). The Dictyostelium discoideum ortholog of WAVE-1 was initially discovered in a genetic screen as a supressor of a cyclic-AMP receptor involved in chemotaxis (Scar; Bear et al. 1998). Subsequently three mammalian orthologs were cloned (WAVE-1, -2, and -3; Miki et al. 1998; Suetsugu et al.
1999). These scaffold proteins act as molecular bridges linking Rho family members to the Arp2/3 complex. WAVE-1 is also a kinase anchoring protein, as it binds PKA and the SH3 domain of the Abelson tyrosine kinase (Abl; Westphal et al. 2000). Proteomic approaches have identified other binding partners that are positive and negative regulators of WAVE function. Rac promotes WAVE-1 activation by causing the release of an inhibitory complex that includes PIR 121, Nap-125, and HSPC300 (Eden et al. 2002). In contrast, signaling through Rac is terminated by a WAVE-1-associated GTPase activating (GAP) protein called WRP (Fig. 3; Soderling et al. 2002). Thus WAVE-1 is capable of recruiting different combinations of signaling enzymes at the neuronal cytoskeleton to control distinct protein phosphorylation and actin remodeling events.

This view is indirectly supported by studies carried out on WAVE-1 "knockout" mice (Soderling et al. 2003). Although there are clear morphological changes in the brain architecture of WAVE-1 knockout mice, the most intriguing observations are the range of behavioral abnormalities detected. Poor performance in the rotarod, inclined screen, and balance beam tests reflects deficits in sensorimotor function that are often indicative of a perturbed cerebellar physiology (Soderling et al. 2003). Likewise, a loss of WAVE-1 from regions of the hippocampus and cortex may underlie the learning and memory deficits that were exposed in the Morris water maze. Collectively, these findings define a physiological role for WAVE-1 in the facilitation of behavioral traits that are regulated by a variety of brain regions. Because the role of WAVE proteins is to provide a molecular platform to assemble protein networks, it is reasonable to propose that the removal of a core organizational component such as the scaffolding protein itself is likely to impede the assembly of these molecular machines. Currently it is unclear whether spatial perturbation of some or all of the WAVE-1 binding partners contributes to the aberrant behavioral phenotypes observed in the knockout mice. However, mislocalization of the newly discovered WAVE-1 binding partner WRP may be significant. Happloinsufficiency of WRP has been linked to 3p-syndrome, a severe form of mental retardation in humans with symptoms that include reduced growth, low IQ, atactic gait, and jerky arm movements (Endris et al. 2002). These symptoms are remarkably similar to the impaired cognitive and sensorimotor functions that were reported for the WAVE-1 knockout mice. WAVE-1 may thus facilitate normal neuronal network connectivity by localizing WRP for its role in the regulation of Rac signaling. Therefore, disruption of actin-based signaling scaffolds that contribute to the formation of synaptic connections may interrupt neuronal responses and be a causative factor in certain disease states. WAVE-1 knockout mice may thus provide an animal model to probe the molecular mechanisms behind cognitive and sensorimotor impairments. Given the number of WAVE-1 binding partners that have been identified to date, it seems likely that the combinatorial assembly of individual signaling networks may provide a mechanism 
Carnegie and Scott

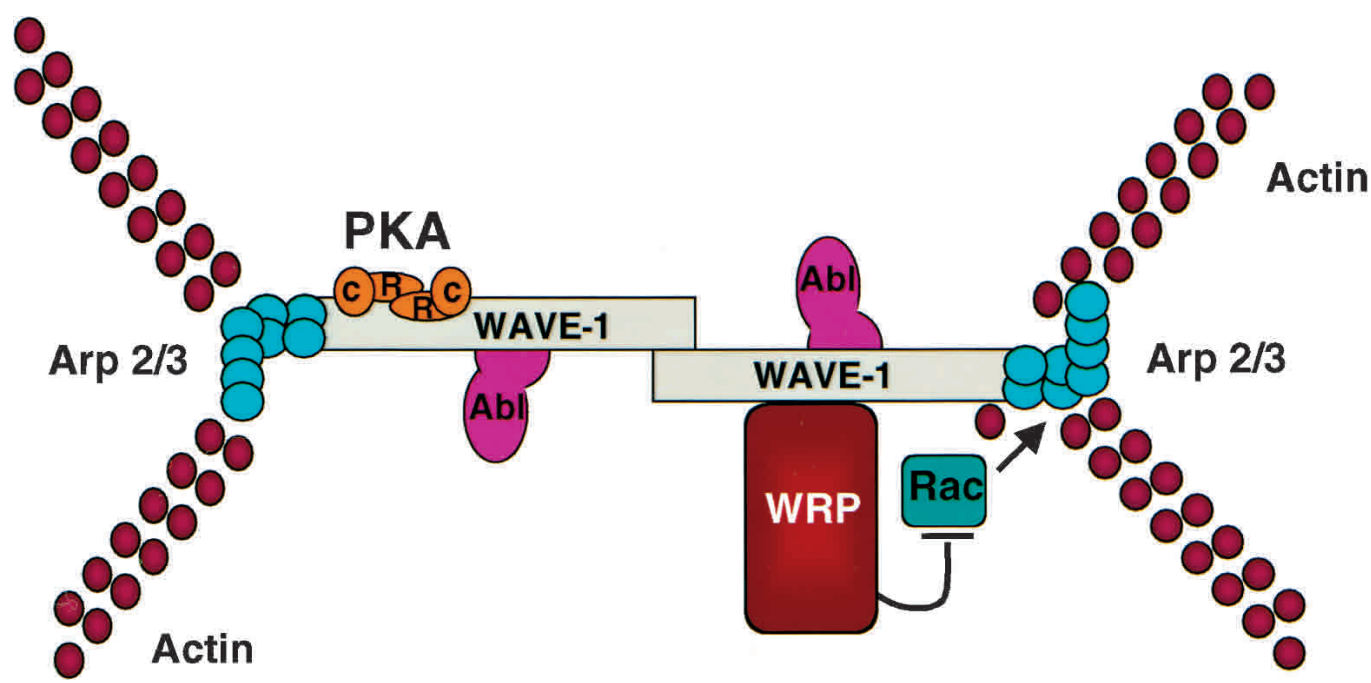

Figure 3. WAVE-1 scaffold model. Illustration of the WAVE-1 signaling complex cross-linked to the actin cytoskeleton. Proteins associated with the WAVE-1 dimer such as the PKA holoenzyme (orange), the tyrosine kinase Abl (pink), the Arp2/3 complex (blue), and the GTPase WRP (red rectangle), which associates with the small G protein Rac (green) are indicated.

for specifying the assembly and function of filamentous actin structures. The functional importance of the various proteins that interact with WAVE-1 may be investigated by carrying out "knock-in" experiments using specific forms of WAVE-1 where individual protein-binding sites are mutated.

AKAP350/CG-NAP/Yotiao A number of AKAP complexes arise from the alternative splicing of a single gene on chromosome 7q21 (Fig. 4). At least four AKAP forms are expressed that are targeted to at least three distinct subcellular locations. Initially, a 120-kD RII-binding fragment was identified and a cDNA encoding a 350-kD protein was isolated from a KE37 human lymphoblastic cell library (Dransfield et al. 1997b; Schmidt et al. 1999). These findings correlated with the biochemical identification of a high-molecular-weight AKAP that was enriched in centrosomal fractions (Keryer et al. 1993). Around the same time, variants encoding AKAP450 and CG-NAP were identified by analysis of bacterial artificial chromosomes and yeast two-hybrid analyses, respectively (Takahashi et al. 1999; Witczak et al. 1999). The latter protein was named CG-NAP on the basis of its detection in centrosomal and Golgi fractions. Detailed analysis of CG-NAP has identified additional binding partners that include protein phosphatase $2 \mathrm{~A}$, the Rhodependent protein kinase PKN, and the protein kinase $\mathrm{C}$ epsilon isoform (Takahashi et al. 1999). Functional studies propose that enzymes in this signaling complex may participate in membrane trafficking, microtubule nucleation, and/or in cell-cycle progression (Takahashi et al. 1999, 2002; Gillingham and Munro 2000). Parallel experiments performed on the AKAP450 form suggest that it interacts with the cAMP phosphodiesterase PDE4D3 (Tasken et al. 2001). This provides a means to tightly regulate cAMP levels and consequently PKA activity at the centrosome. Interestingly, the compartmentalized PDE4D3 may also influence the activa- tion state of the PKA pool that is tethered at this site through its association with another centrosomal AKAP called pericentrin (Diviani et al. 2000). Because AKAP450 and pericentrin both contain a C-terminal pericentrin AKAP450 centrin (PAC) domain, it is possible that they interact with the same structural elements at the centrosome (Gillingham and Munro 2000). This apparent redundancy in PKA anchoring may ensure that the kinase is always anchored to this organelle for an as yet unidentified essential role in some aspect of centrosomal function.

In contrast, yotiao, the shortest splice variant of this family is targeted to submembrane sites where it anchors PKA and protein phosphatase 1 (PP1; Westphal et al. 1999). Yotiao was identified in a yeast two-hybrid screen for proteins interacting with the $\mathrm{C} 1$ exon in the cytoplasmic tail of NR1A subunit of the NMDA receptor (Lin et al. 1998). Consequently, yotiao regulates channel activity by altering the phosphorylation state of hippocampal NR1A receptors. Favoring NR1A phosphorylation by displacing PP1 from yotiao with a PP1-binding peptide or by inhibiting phosphatase activity with okadaic acid increases NMDA receptor currents, whereas tonic PP1 activity negatively regulates NMDA receptors (Westphal et al. 1999). This model of channel regulation mediated by yotiao is depicted in Figure 5. More recently a requirement for yotiao targeting of PKA and PP1 to GABA(A) receptors at inhibitory synapses was demonstrated in the dopaminergic regulation of cognitive processes, and yotiao's interaction with potassium channels was inferred for the control of certain cardiac functions (Wang et al. 2002). Collectively, the AKAP350/450 CG-NAP/yotiao family are capable of targeting PKA and a plethora of other signaling enzymes (see Fig. 4) to a variety of subcellular locations. These complexities are underscored by evidence that individual enzyme-binding sites and organelle targeting domains are encoded by different exons. A more detailed analysis will be required to 
Genomic sequence

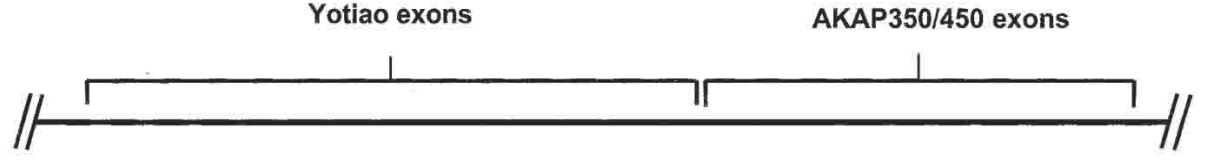

Human AKAP450 gene (Chr.7q21-22)

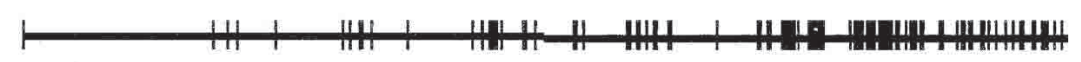

Yotiao

Characterized isoforms

AKAP350
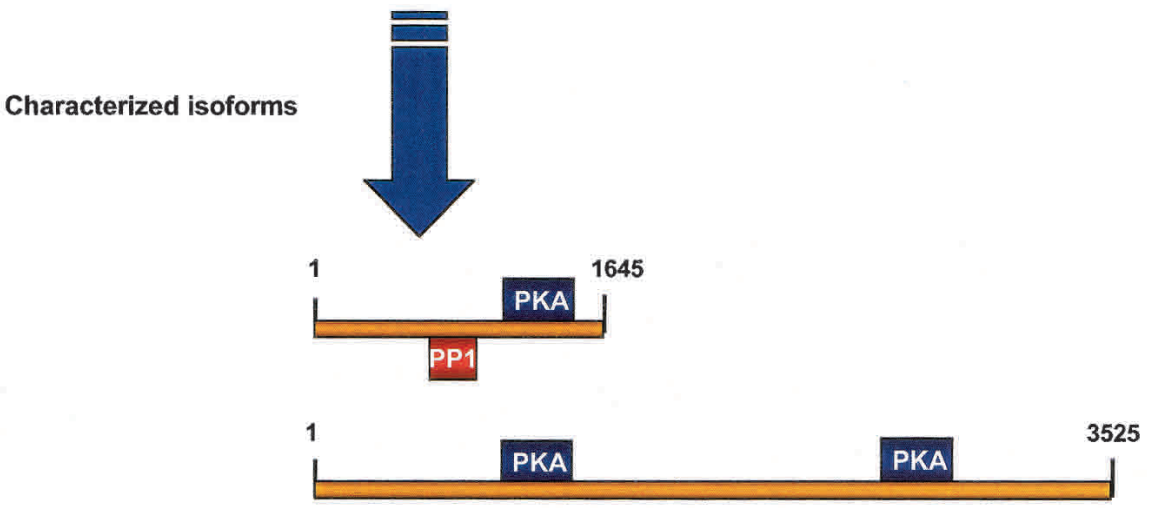

CG-NAP

(AKAP450)

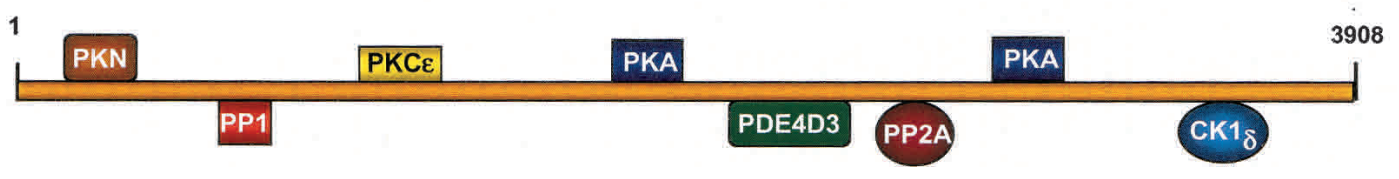

Figure 4. AKAP splice variants. (Top) Schematic diagram of the human genomic sequence encompassing the AKAP450 gene. Fifty exons are believed to encode various splice variants of this gene and are represented by the vertical lines marked along the gene. (Bottom) Diagram illustrating the major characterized isoforms encoded by the AKAP450 gene and their binding partners.

establish whether each AKAP form transcribed from this gene contains only one targeting domain. Transcriptional regulation is undoubtedly a critical determinant for location and composition of each signaling complex maintained by this gene product.
Conclusions and Perspectives

AKAPs are a diverse family of "signal organizing" proteins that contribute to the precision of intracellular signaling events by directing their anchored enzymes to-

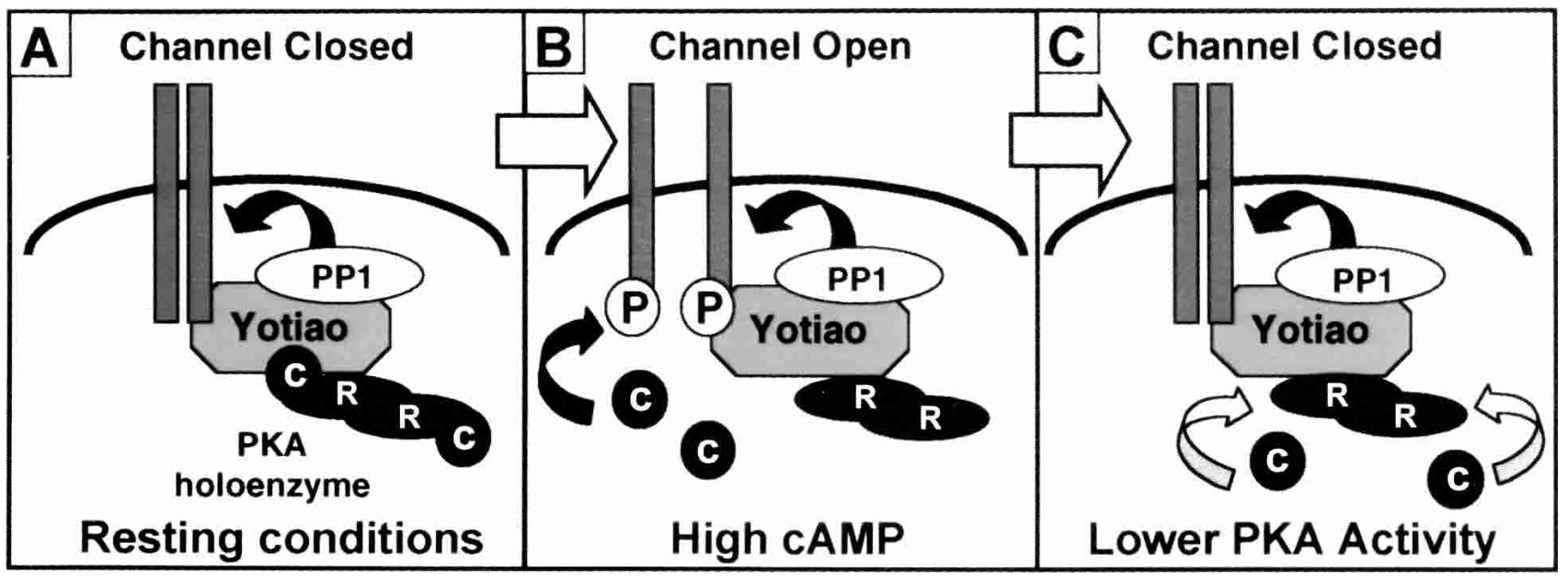

Figure 5. Yotiao scaffold model; regulation of the NMDA receptor. $(A)$ Under resting conditions, active PP1 may favor the dephosphorylation and therefore inactivation of channels. $(B)$ Upon cAMP stimulation, PKA catalytic subunit is released and phosphorylates NMDA receptors, overcoming PP1 basal activity. This allows the channel to open and enhances the current through NMDA channels. (C) Metabolism of cAMP pools facilitates reformation of the PKA holoenzyme, allowing PP1 dephosphorylation of NMDA receptors to predominate, thereby causing channel deactivation. 
ward a subset of their physiological substrates. Historically, the evidence to support their function has been gleaned from analysis of PKA phosphorylation events; however, AKAP-mediated compartmentalization of other signaling enzymes is equally important. For example, AKAP350/CG-NAP, AKAP220, and WAVE-1 assemble functional protein networks that contribute to Rho kinase signaling, glycogen synthase kinase 3 action, and Rac-mediated actin remodeling, respectively (Takahashi et al. 2000; Soderling et al. 2002; Tanji et al. 2002). Another example is the AKAP79/150-mediated anchoring of $\mathrm{PKC} \beta$ for a role in the suppression of $\mathrm{M}$ currents in SCG neurons (Hoshi et al. 2003). Undoubtedly, additional cAMP-independent signaling events will be ascribed to AKAP-mediated targeting of enzymes, and functional signaling complexes may be formed that do not involve PKA.

One important property of AKAPs is to compartmentalize signal termination enzymes. This is exemplified by yotiao, AKAP220, and AKAP149, which tether protein phosphatase 1 to oppose the action of anchored kinase counterparts (Schillace and Scott 1999; Westphal et al. 1999; Steen et al. 2000). This creates an environment where protein phosphorylation is only favored when kinase activity is sufficiently stimulated to overcome these basal dephosphorylation events. Another variation on this theme occurs where anchored signal termination enzymes act upstream of protein phosphorylation events. For example, AKAP450 and mAKAP colocalize a cAMP-metabolizing enzyme PDE4D3 with a cAMP-dependent protein kinase such that anchored phosphodiesterase reduces cAMP levels in the vicinity of the kinase (Dodge et al. 2001; Tasken et al. 2001). These signaling complexes not only contribute to the formation of intracellular gradients of cAMP but also contribute to the spatial and temporal resolution of PKA signaling by generating pulses of kinase activity.

In conclusion, it seems appropriate to speculate on some emerging aspects of AKAP research. These include detailed proteomic dissection of AKAP complexes (Eden et al. 2002; Soderling et al. 2002), the identification of distinct determinants on the AKAPs that confer type I or type II PKA anchoring (Alto et al. 2003) and the detection of genetic polymorphisms in D-AKAP2 that may correlate with cardiovascular signaling defects in the aging population (Kammerer et al. 2003). Particular mention should be given to behavioral and electrophysiological studies that have implicated AKAP complexes in the control of neural processes that underlie different forms of learning and memory. Displacement of PKA from AKAPs in the lateral amygdala depresses auditory fear conditioning in rats, whereas treatment of hippocampal slices with anchoring inhibitor peptides occludes synaptically induced long-term depression (LTD; Moita et al. 2002; E.M. Snyder, M. Colledge, R.A. Crozier, J.D. Scott, and M.F. Bear, in prep.). AKAP79/150 has been implicated in the modulation of both neuronal behaviors, although more definitive analyses are necessary to confirm this notion. PKA anchoring may also contribute to the surface expression of AMPA channels by orchestrating signaling events that promote AMPA receptor endocytosis. On the basis of their postsynaptic location, AKAP79/ 150 and yotiao seem reasonable candidates to fulfill this function, although another possibility is neurobeachin, a recently identified postsynaptic AKAP that contains a BEACH-WD40 domain (Wang et al. 2000). This protein is believed to interact with the protein sorting machinery, including endosomes, lysosomes, and the plasma membrane (Nagle et al. 1996). Thus regulation of AMPA receptor trafficking may involve several AKAP networks that coordinate signaling at different phases of the endocytic pathway. Finally, exhaustive database searches have traced the conservation of certain AKAPs from Caenorhabditis elegans and Drosophila melanogaster to mammals. Perhaps the most intriguing findings come from analysis of the Zebrafish genome, where WAVE-1, mAKAP, AKAP79, and AKAP18 orthologs have been identified with surprisingly high homology to their mammalian counterparts. Characterization and genetic manipulation of these putative AKAPs may provide a means to study the role of PKA anchoring in neural development.

\section{Acknowledgments}

We thank Neal Alto, Marcie Colledge, Jen Michell, Scott Soderling, and other members of the Scott lab for providing some of the figures presented and critical evaluation of the manuscript. This work was supported in part through NIH grant GM48231.

\section{References}

Adams, S.R., Harootunian, A.T., Buechler, Y.J., Taylor, S.S., and Tsien, R.Y. 1991. Fluorescence ratio imaging of cyclic AMP in single cells. Nature 349: 694-697.

Alto, N.M., Soderling, J., and Scott, J.D. 2002. Rab32 is an Akinase anchoring protein and participates in mitochondrial dynamics. J. Cell Biol. 158: 659-668.

Alto, N.M., Soderling, S.H., Hoshi, N., Langeberg, L.K., Fayos, R., Jennings, P.A., and Scott, J.D. 2003. Bioinformatic design of A-kinase anchoring protein-in silico: A potent and selective peptide antagonist of type II protein kinase A anchoring. Proc. Natl. Acad. Sci. 100: 4445-4450.

Angelo, R. and Rubin, C.S. 1998. Molecular characterization of an anchor protein $\left(\mathrm{AKAP}_{\mathrm{CE}}\right)$ that binds the RI subunit $\left(\mathrm{R}_{\mathrm{CE}}\right)$ of type I protein kinase A from Caenorhabditis elegans. I. Biol. Chem. 273: 14633-14643.

Bacskai, B.J., Hochner, B., Mahaut-Smith, M., Adams, S.R., Kaang, B.-K., Kandel, E.R., and Tsien, R.Y. 1993. Spatially resolved dynamics of cAMP and protein kinase A subunits in aplysia sensory neurons. Science 260: 222-226.

Banky, P., Newlon, M.G., Roy, M., Garrod, S., Taylor, S.S., and Jennings, P.A. 2000. Isoform-specific differences between the type I- $\alpha$ and II- $\alpha$ cyclic AMP-dependent protein kinase anchoring domains revealed by solution NMR. I. Biol. Chem. 275: 35146-35152.

Barford, D., Hu, S.H., and Johnson, L.N. 1991. Structural mechanism for glycogen phosphorylase control by phosphorylation and AMP. J. Mol. Biol. 218: 233-260.

Barsony, J. and Marks, S.J. 1990. Immunocytology on microwave-fixed cells reveals rapid and agonist-specific changes in subcellular accumulation patterns for cAMP or cGMP. Proc. Nat1. Acad. Sci. 87: 1188-1192.

Bauman, A.L. and Scott, J.D. 2002. Kinase- and phosphatase- 
anchoring proteins: Harnessing the dynamic duo. Nat. Cell Biol. 4: 203-206.

Bear, J.E., Rawls, J.F., and Saxe III, C.L. 1998. SCAR, a WASPrelated protein, isolated as a suppressor of receptor defects in late Dictyostelium development. I. Cell Biol. 142: 13251335.

Beavo, J.A. and Brunton, L.L. 2002. Cyclic nucleotide researchStill expanding after half a century. Nat. Rev. Mol. Cell Biol. 3: 710-718.

Brandon, E.P., Gerhold, K.A., Qi, M., McKnight, G.S., and Idzerda, R.L. 1995. Derivation of novel embryonic stem cell lines and targeting of cyclic AMP-dependent protein kinase genes. Recent Prog. Horm. Res. 50: 403-408.

Brandon, E.P., Idzerda, R.L., and McKnight, G.S. 1997. PKA isoforms, neural pathways, and behaviour: Making the connection. Curr. Opin. Neurobiol. 7: 397-403.

Brandon, N.J., Jovanovic, J.N., Colledge, M., Kittler, J.T., Brandon, J.M., Scott, J.D., and Moss, S.J. 2003. A-kinase anchoring protein $79 / 150$ facilitates the phosphorylation of GABA(A) receptors by cAMP-dependent protein kinase via selective interaction with receptor $\beta$ subunits. Mol. Cell Neurosci. 22: 87-97.

Bregman, D.B., Bhattacharyya, N., and Rubin, C.S. 1989. High affinity binding protein for the regulatory subunit of cAMPdependent protein kinase II-B. Cloning, characterization, and expression of cDNAs for rat brain P150. J. Biol. Chem. 264: 4648-4656.

Bregman, D.B., Hirsch, A.H., and Rubin, C.S. 1991. Molecular characterization of bovine brain $\mathrm{P} 75$, a high affinity binding protein for the regulatory subunit of cAMP-dependent protein kinase II $\beta$. J. Biol. Chem. 266: 72077213.

Burack, W.R. and Shaw, A.S. 2000. Signal transduction: Hanging on a scaffold. Curr. Opin. Cell Biol. 12: 211-216.

Burns-Hamuro, L.L., Ma, Y., Kammerer, S., Reineke, U., Self, C., Cook, C., Olson, G.L., Cantor, C.R., Braun, A., and Taylor, S.S. 2003. Designing isoform-specific peptide disruptors of protein kinase A localization. Proc. Natl. Acad. Sci. 100: 4072-4077.

Burton, K.A., Johnson, B.D., Hausken, Z.E., Westenbroek, R.E., Idzerda, R.L., Scheuer, T., Scott, J.D., Catterall, W.A., and McKnight, G.S. 1997. Type II regulatory subunits are not required for the anchoring-dependent modulation of $\mathrm{Ca}^{2+}$ channel activity by cAMP-dependent protein kinase. Proc. Natl. Acad. Sci. 94: 11067-11072.

Cantley, L.C., Auger, K.R., Carpenter, C., Duckworth, B., Graziani, A., Kapeller, R., and Soltoff, S. 1991. Oncogenes and signal transduction. Cell 64: 281-302.

Carr, D.W. and Scott, J.D. 1992. Blotting and band-shifting: Techniques for studying protein-protein interactions. Trends Biochem. Sci. 17: 246-249.

Carr, D.W., Stofko-Hahn, R.E., Fraser, I.D.C., Bishop, S.M., Acott, T.S., Brennan, R.G., and Scott, J.D. 1991. Interaction of the regulatory subunit (RII) of cAMP-dependent protein kinase with RII-anchoring proteins occurs through an amphipathic helix binding motif. J. Biol. Chem. 266: 1418814192.

Carr, D.W., Hausken, Z.E., Fraser, I.D., Stofko-Hahn, R.E., and Scott, J.D. 1992a. Association of the type II cAMP-dependent protein kinase with a human thyroid RII-anchoring protein. Cloning and characterization of the RII-binding domain. $J$. Biol. Chem. 267: 13376-13382.

Carr, D.W., Stofko-Hahn, R.E., Fraser, I.D.C., Cone, R.D., and Scott, J.D. 1992b. Localization of the cAMP-dependent protein kinase to the postsynaptic densities by A-kinase anchoring proteins: Characterization of AKAP79. J. Biol. Chem.
24: $16816-16823$.

Cho, K., Brown, M.W., and Bashir, Z.I. 2002. Mechanisms and physiological role of enhancement of mGlu5 receptor function by group II mGlu receptor activation in rat perirhinal cortex. J. Physiol. 540: 895-906.

Chrivia, J.C., Uhler, M.D., and McKnight, G.S. 1988. Characterization of genomic clones coding for the $\mathrm{Ca}$ and $\mathrm{Cb}$ subunits of mouse cAMP-dependent protein kinase. J. Biol. Chem. 263: 5739-5744.

Coghlan, V.M., Langeberg, L.K., Fernandez, A., Lamb, N.J.C., and Scott, J.D. 1994. Cloning and characterization of AKAP95, a nuclear protein that associates with the regulatory subunit of type II cAMP-dependent protein kinase. J. Biol. Chem. 269: 7658-7665.

Coghlan, V.M., Perrino, B.A., Howard, M., Langeberg, L.K., Hicks, J.B., Gallatin, W.M., and Scott, J.D. 1995. Association of protein kinase A and protein phosphatase 2B with a common anchoring protein. Science 267: 108-112.

Cohen, P. 1999. The development and therapeutic potential of protein kinase inhibitors. Curr. Opin. Chem. Biol. 3: 459465.

- 2000. The regulation of protein function by multisite phosphorylation-A 25 year update. Trends Biochem. Sci. 25: 596-601.

Colledge, M. and Scott, J.D. 1999. AKAPs: From structure to function. Trends Cell Biol. 9: 216-221.

Colledge, M., Dean, R.A., Scott, G.K., Langeberg, L.K., Huganir, R.L., and Scott, J.D. 2000. Targeting of PKA to glutamate receptors through a MAGUK-AKAP complex. Neuron 27: 107-119.

Cong, M., Perry, S.J., Lin, F.T., Fraser, I.D., Hu, L.A., Chen, W., Pitcher, J.A., Scott, J.D., and Lefkowitz, R.J. 2001. Regulation of membrane targeting of the $\mathrm{G}$ protein-coupled receptor kinase 2 by Protein Kinase A and its anchoring protein AKAP79. J. Biol. Chem. 276: 15192-15199.

Corbin, J.D. and Keely, S.L. 1977. Characterization and regulation of heart adenosine 3': 5'-monophosphate-dependent protein kinase isozymes. J. Biol. Chem. 252: 910-918.

Corbin, J.D., Soderling, T.R., and Park, C.R. 1973. Regulation of adenosine $3^{\prime}, 5^{\prime}$-monophosphate-dependent protein kinase. J. Biol. Chem. 248: 1813-1821.

Dart, C. and Leyland, M.L. 2001. Targeting of an A kinaseanchoring protein, AKAP79, to an inwardly rectifying potassium channel, Kir2.1. J. Biol. Chem. 276: 2049920505.

Davare, M.A., Dong, F., Rubin, C.S., and Hell, J.W. 1999. The A-kinase anchor protein MAP2B and cAMP-dependent protein kinase are associated with class C L-type calcium channels in neurons. J. Biol. Chem. 274: 30280-30287.

Dell'Acqua, M.L. and Scott, J.D. 1997. Protein kinase A anchoring. J. Biol. Chem. 272: 12881-12884.

Dell'Acqua, M.L., Faux, M.C., Thorburn, J., Thorburn, A., and Scott, J.D. 1998. Membrane-targeting sequences on AKAP79 bind phosphatidylinositol-4,5-bisphosphate. EMBO J. 17: 2246-2260

Dell'Acqua, M.L., Dodge, K.L., Tavalin, S.J., and Scott, J.D. 2002. Mapping the protein phosphatase-2B anchoring site on AKAP79. Binding and inhibition of phosphatase activity are mediated by residues 315-360. J. Biol. Chem. 277: 4879648802.

de Rooij, J., Rehmann, H., van Triest, M., Cool, R.H., Wittinghofer, A., and Bos, J.L. 2000. Mechanism of regulation of the Epac family of cAMP-dependent RapGEFs. J. Biol. Chem. 275: 20829-20836.

Diviani, D., Langeberg, L.K., Doxsey, S.J., and Scott, J.D. 2000. Pericentrin anchors protein kinase $\mathrm{A}$ at the centrosome 
through a newly identified RII-binding domain. Curr. Biol. 10: $417-420$.

Diviani, D., Soderling, J., and Scott, J.D. 2001. AKAP-Lbc anchors protein kinase A and nucleates $\mathrm{G} \alpha$ 12-selective Rhomediated stress fiber formation. J. Biol. Chem. 276: 4424744257.

Dodge, K. and Scott, J.D. 2000. AKAP79 and the evolution of the AKAP model. FEBS Lett. 476: 58-61.

Dodge, K.L., Khouangsathiene, S., Kapiloff, M.S., Mouton, R., Hill, E.V., Houslay, M.D., Langeberg, L.K., and Scott, J.D. 2001. mAKAP assembles a protein kinase A/PDE4 phosphodiesterase cAMP signaling module. EMBO J. 20: 19211930.

Dransfield, D.T., Bradford, A.J., Smith, J., Martin, M., Roy, C., Mangeat, P.H., and Goldenring, J.R. 1997a. Ezrin is a cyclic AMP-dependent protein kinase anchoring protein. EMBO $J$. 16: 101-109.

Dransfield, D.T., Yeh, J.L., Bradford, A.J., and Goldenring, J.R. 1997b. Identification and characterization of a novel A-kinase-anchoring-protein (AKAP120) from rabbit gastric parietal cells. Biochem. J. 322: 801-808.

Eden, S., Rohatgi, R., Podtelejnikov, A.V., Mann, M., and Kirschner, M.W. 2002. Mechanism of regulation of WAVE1induced actin nucleation by Rac1 and Nck. Nature 418: 790793.

Endris, V., Wogatzky, B., Leimer, U., Bartsch, D., Zatyka, M., Latif, F., Maher, E.R., Tariverdian, G., Kirsch, S., Karch, D., et al. 2002. The novel Rho-GTPase activating gene MEGAP/ srGAP3 has a putative role in severe mental retardation. Proc. Natl. Acad. Sci. 99: 11754-11759.

Faux, M.C. and Scott, J.D. 1997. Regulation of the AKAP79protein kinase $\mathrm{C}$ interaction by $\mathrm{Ca}^{2+} /$ calmodulin. J. Biol. Chem. 272: 17038-17044.

Faux, M.C., Rollins, E.N., Edwards, A.S., Langeberg, L.K., Newton, A.C., and Scott, J.D. 1999. Mechanism of A-kinase-anchoring protein 79 (AKAP79) and protein kinase C interaction. Biochem. J. 343: 443-452.

Feliciello, A., Gottesman, M.E., and Avvedimento, E.V. 2001. The biological functions of A-kinase anchor proteins. J. Mol. Biol. 308: 99-114.

Fischer, E.H. and Krebs, E.G. 1955. Conversion of phosphorylase $b$ to phosphorylase $a$ in muscle extracts. J. Biol. Chem. 216: 121-132.

Fraser, I.D., Tavalin, S.J., Lester, L.B., Langeberg, L.K., Westphal, A.M., Dean, R.A., Marrion, N.V., and Scott, J.D. 1998. A novel lipid-anchored A-kinase Anchoring Protein facilitates cAMP-responsive membrane events. EMBO $I$. 17: 2261-2272.

Fraser, I., Cong, M., Kim, J., Rollins, E., Daaka, Y., Lefkowitz, R., and Scott, J. 2000. Assembly of an AKAP/ $\beta 2$-adrenergic receptor signaling complex facilitates receptor phosphorylation and signaling. Curr. Biol. 10: 409-412.

Gao, T., Yatani, A., Dell'Acqua, M.L., Sako, H., Green, S.A., Dascal, N., Scott, J.D., and Hosey, M.M. 1997. cAMP-dependent regulation of cardiac L-type $\mathrm{Ca}^{2+}$ channels requires membrane targeting of PKA and phosphorylation of channel subunits. Neuron 19: 185-196.

Gibbs, C.S., Knighton, D.R., Sowadski, J.M., Taylor, S.S., and Zoller, M.J. 1992. Systematic mutational analysis of cAMPdependent protein kinase identifies unregulated catalytic subunits and defines regions important for the recognition of the regulatory subunit. J. Biol. Chem. 267: 4806-4814.

Gillingham, A.K. and Munro, S. 2000. The PACT domain, a conserved centrosomal targeting motif in the coiled-coil proteins AKAP450 and pericentrin. EMBO Rep. 1: 524529.
Goodman, R.H. and Smolik, S. 2000. CBP/p300 in cell growth, transformation, and development. Genes \& Dev. 14: 15531577.

Gray, P.C., Tibbs, V.C., Catterall, W.A., and Murphy, B.J. 1997. Identification of a $15-\mathrm{kDa}$ cAMP-dependent protein kinaseanchoring protein associated with skeletal muscle L-type calcium channels. J. Biol. Chem. 272: 6297-6302.

Gray, P.C., Johnson, B.D., Westenbroek, R.E., Hays, L.G., Yates, J.R., Scheuer, T., Catterall, W.A., and Murphy, B.J. 1998. Primary structure and function of an A kinase anchoring protein associated with calcium channels. Neuron 20: 10171026.

Harada, A., Teng, J., Takei, Y., Oguchi, K., and Hirokawa, N. 2002. MAP2 is required for dendrite elongation, PKA anchoring in dendrites, and proper PKA signal transduction. J. Cell Biol. 158: 541-549.

Herberg, F.W., Maleszka, A., Eide, T., Vossebein, L., and Tasken, K. 2000. Analysis of A-Kinase Anchoring Protein (AKAP) interaction with Protein Kinase A (PKA) regulatory subunits: PKA isoform specificity in AKAP binding. J. Mol. Biol. 298: 329-339.

Hoshi, N., Zhang, J.-S., Omaki, M., Takeuchi, T., Yokoyama, S., Wanaverbecq, N., Langeberg, L., Yoneda, Y., Scott, J.D., Brown, D.A., et al. 2003. AKAP150 signaling complex promotes suppression of the M-current by muscarinic agonists. Nature Neurosci. 6: 564-571.

Houslay, M.D. 2001. PDE4 cAMP-specific phosphodiesterases. Prog. Nucleic. Acid Res. Mol. Biol. 69: 249-315.

Huang, L.J., Durick, K., Weiner, J.A., Chun, J., and Taylor, S.S. 1997a. D-AKAP2, a novel protein kinase A anchoring protein with a putative RGS domain. Proc. Natl. Acad. Sci. 94: 11184-11189.

- 1997b. Identification of a novel dual specificity protein kinase A anchoring protein, D-AKAP1. I. Biol. Chem. 272: 8057-8064.

Huang, L.J., Wang, L., Ma, Y., Durick, K., Perkins, G., Deerinck, T.J., Ellisman, M.H., and Taylor, S.S. 1999. NH2-Terminal targeting motifs direct dual specificity A-kinase-anchoring protein 1 (D-AKAP1) to either mitochondria or endoplasmic reticulum. J. Cell Biol. 145: 951-959.

Hulme, J.T., Ahn, M., Hauschka, S.D., Scheuer, T., and Catterall, W.A. 2002. A novel leucine zipper targets AKAP15 and cyclic AMP-dependent protein kinase to the $\mathrm{C}$ terminus of the skeletal muscle $\mathrm{Ca}^{2+}$ channel and modulates its function. J. Biol. Chem. 277: 4079-4087.

Hunter, T. 1987. A thousand and one protein kinases. Cell 50: $823-829$.

- 1995. Protein kinases and phosphatases: The yin and yang of protein phosphorylation and signaling. Cell 80: 225236.

- 2000. Signaling-2000 and beyond. Cell 100: 113-127.

Itoh, T.J., Hisanaga, S., Hosoi, T., Kishimoto, T., and Hotani, H. 1997. Phosphorylation states of microtubule-associated protein 2 (MAP2) determine the regulatory role of MAP2 in microtubule dynamics. Biochemistry 36: 12574 12582.

Johnson, L.N. and Barford, D. 1990. Glycogen phosphorylase. The structural basis of the allosteric response and comparison with other allosteric proteins. J. Biol. Chem. 265: 24092412.

Johnson, L.N. and O'Reilly, M. 1996. Control by phosphorylation. Curr. Opin. Struct. Biol. 6: 762-769.

Jordan, J.D., Landau, E.M., and Iyengar, R. 2000. Signaling networks: The origins of cellular multitasking. Cell 103: 193200.

Kammerer, S., Burns-Hamuro, L.L., Ma, Y., Hamon, S.C., Canaves, 
J.M., Shi, M.M., Nelson, M.R., Sing, C.F., Cantor, C.R., Taylor, S.S., et al. 2003. Amino acid variant in the kinase binding domain of dual-specific A kinase-anchoring protein 2: A disease susceptibility polymorphism. Proc. Natl. Acad. Sci. 100: 4066-4071.

Kapiloff, M.S. 2002. Contributions of protein kinase A anchoring proteins to compartmentation of cAMP signaling in the heart. Mol. Pharmacol. 62: 193-199.

Kaupp, U.B. and Seifert, R. 2002. Cyclic nucleotide-gated ion channels. Physiol. Rev. 82: 769-824.

Keryer, G., Rios, R.M., Landmark, B.F., Skalhegg, B., Lohmann, S.M., and Bornens, M. 1993. A high-affinity binding protein for the regulatory subunit of cAMP-dependent protein kinase II in the centrosome of human cells. Exp. Cell Res. 204: 230-240.

Kind, P.C. and Neumann, P.E. 2001. Plasticity: Downstream of glutamate. Trends Neurosci. 24: 553-555.

Klauck, T.M., Faux, M.C., Labudda, K., Langeberg, L.K., Jaken, S., and Scott, J.D. 1996. Coordination of three signaling enzymes by AKAP79, a mammalian scaffold protein. Science 271: 1589-1592.

Krebs, E.G. 1985. The phosphorylation of proteins: A major mechanism for biological regulation. Biochem. Soc. Trans. 13: $813-820$.

Kussel-Andermann, P., El-Amraoui, A., Safieddine, S., Hardelin, J.P., Nouaille, S., Camonis, J., and Petit, C. 2000. Unconventional myosin VIIA is a novel A-kinase-anchoring protein. $J$. Biol. Chem. 275: 29654-29659.

Lee, D.C., Carmichael, D.F., Krebs, E.G., and McKnight, G.S. 1983. Isolation of cDNA clone for the type I regulatory subunit of bovine cAMP-dependent protein kinase. Proc. Natl. Acad. Sci. 80: 3608-3612.

Lee, H.K., Kameyama, K., Huganir, R.L., and Bear, M.F. 1998. NMDA induces long-term synaptic depression and dephosphorylation of the GluR1 subunit of AMPA receptors in hippocampus. Neuron 21: 1151-1162.

Lester, L.B., Langeberg, L.K., and Scott, J.D. 1997. Anchoring of protein kinase A facilitates hormone-mediated insulin secretion. Proc. Natl. Acad. Sci. 94: 14942-14947.

Li, H., Degenhardt, B., Tobin, D., Yao, Z.X., Tasken, K., and Papadopoulos, V. 2001. Identification, localization, and function in steroidogenesis of PAP7: A peripheral-type benzodiazepine receptor- and PKA (RI $\alpha)$-associated protein. Mol. Endocrinol. 15: 2211-2228.

Lin, J.W., Wyszynski, M., Madhavan, R., Sealock, R., Kim, J.U., and Sheng, M. 1998. Yotiao, a novel protein of neuromuscular junction and brain that interacts with specific splice variants of NMDA receptor subunit NR1. J. Neurosci. 18: 20172027.

Livesey, S.A., Kemp, B.E., Re, C.A., Partridge, N.C., and Martin, T.J. 1982. Selective hormonal activation of cyclic AMP-dependent protein kinase isoenzymes in normal and malignant osteoblasts. J. Biol. Chem. 257: 14983-14987.

Lohmann, S.M., DeCamili, P., Enig, I., and Walter, U. 1984. High-affinity binding of the regulatory subunit (RII) of cAMP-dependent protein kinase to microtubule-associated and other cellular proteins. Proc. Natl. Acad. Sci. 81: 67236727.

Machesky, L.M. and Insall, R.H. 1998. Scar1 and the related Wiskott-Aldrich syndrome protein, WASP, regulate the actin cytoskeleton through the Arp2/3 complex. Curr. Biol. 8: $1347-1356$.

. 1999. Signaling to actin dynamics. J. Cell Biol. 146: 267272.

Machesky, L.M., Mullins, R.D., Higgs, H.N., Kaiser, D.A., Blanchoin, L., May, R.C., Hall, M.E., and Pollard, T.D. 1999. Scar, a WASp-related protein, activates nucleation of actin filaments by the Arp2/3 complex. Proc. Natl. Acad. Sci. 96: $3739-3744$.

Malenka, R.C. and Nicoll, R.A. 1999. Long-term potentiation-A decade of progress? Science 285: 1870-1874.

Malinow, R. and Malenka, R.C. 2002. AMPA receptor trafficking and synaptic plasticity. Annu. Rev. Neurosci. 25: 103 126.

Miki, K. and Eddy, E.M. 1999. Single amino acids determine specificity of binding of protein kinase A regulatory subunits by protein kinase A anchoring proteins I. Biol. Chem. 274: 29057-29062.

Miki, H., Suetsugu, S., and Takenawa, T. 1998. WAVE, a novel WASP-family protein involved in actin reorganization induced by Rac. EMBO J. 17: 6932-6941.

Moita, M.A., Lamprecht, R., Nader, K., and LeDoux, J.E. 2002. A-kinase anchoring proteins in amygdala are involved in auditory fear memory. Nat. Neurosci. 5: 837-838.

Moss, S.B. and Gerton, G.L. 2001. A-kinase anchor proteins in endocrine systems and reproduction. Trends Endocrinol. Metab. 12: 434-440.

Nagle, D.L., Karim, M.A., Woolf, E.A., Holmgren, L., Bork, P., Misumi, D.J., McGrail, S.H., Dussault Jr., B.J., Perou, C.M., Boissy, R.E., et al. 1996. Identification and mutation analysis of the complete gene for Chediak-Higashi syndrome. Nat. Genet. 14: 307-311.

Newlon, M.G., Roy, M., Hausken, Z.E., Scott, J.D., and Jennings, P.A. 1997. The A-kinase anchoring domain of Type IIa cAMP-dependent protein kinase is highly helical. J. Biol. Chem. 272: 23637-23644.

Newlon, M.G., Roy, M., Morikis, D., Hausken, Z.E., Coghlan, V., Scott, J.D., and Jennings, P.A. 1999. The molecular basis for protein kinase A anchoring revealed by solution NMR. Nat. Struct. Biol. 6: 222-227.

Newlon, M.G., Roy, M., Morikis, D., Carr, D.W., Westphal, R., Scott, J.D., and Jennings, P.A. 2001. A novel mechanism of PKA anchoring revealed by solution structures of anchoring complexes. EMBO J. 20: 1651-1662.

Oliveria, S.F., Gomez, L.L., and Dell'Acqua, M.L. 2003. Imaging kinase-AKAP79-phosphatase scaffold complexes at the plasma membrane in living cells using FRET microscopy. J. Cell Biol. 160: 101-112.

Pawson, T. 1995. Protein modules and signalling networks. Nature 373: 573-580.

Pawson, T. and Gish, G.D. 1992. SH2 and SH3 domains: From structure to function. Cell 71: 359-362.

Pawson, T. and Nash, P. 2000. Protein-protein interactions define specificity in signal transduction. Genes \& Dev. 14: $1027-1047$

Pawson, T. and Scott, J.D. 1997. Signaling through scaffold, anchoring, and adaptor proteins. Science 278: 20752080.

Potter, R.L. and Taylor, S.S. 1979. Correlation of the cAMP binding domain with a site of autophosphorylation on the regulatory subunit of cAMP-dependent protein kinase II from porcine skeletal muscle. I. Biol. Chem. 254: 9000-9005.

Potter, R.L., Stafford, P.H., and Taylor, S. 1978. Regulatory subunit of cyclic AMP-dependent protein kinase I from porcine skeletal muscle: Purification and proteolysis. Arch. Biochem. Biophys. 190: 174-180.

Rall, T.W. and Sutherland, E.W. 1958. Formation of cyclic adenine ribonucleotide by tissue particles. I. Biol. Chem. 232: $1065-1076$

Rall, T.W., Sutherland, E.W., and Berthet, J. 1957. The relationships of epinephrine and glucagon to liver phosphorylase. J. 
Biol. Chem. 224: 463-475.

Robinson, R.C., Turbedsky, K., Kaiser, D.A., Marchand, J.B., Higgs, H.N., Choe, S., and Pollard, T.D. 2001. Crystal structure of Arp2/3 complex. Science 294: 1679-1684.

Rohatgi, R., Ma, L., Miki, H., Lopez, M., Kirchhausen, T., Takenawa, T., and Kirschner, M.W. 1999. The interaction between N-WASP and the Arp2/3 complex links Cdc42-dependent signals to actin assembly. Cell 97: 221-231.

Rosenmund, C., Carr, D.W., Bergeson, S.E., Nilaver, G., Scott, J.D., and Westbrook, G.L. 1994. Anchoring of protein kinase $\mathrm{A}$ is required for modulation of AMPA/kainate receptors on hippocampal neurons. Nature 368: 853-856.

Rubin, C.S. 1994. A kinase anchor proteins and the intracellular targeting of signals carried by cAMP. Biochim. Biophys. Acta. 1224: 467-479.

Sarkar, D., Erlichman, J., and Rubin, C.S. 1984. Identification of a calmodulin-binding protein that copurifies with the regulatory subunit of brain protein kinase II. J. Biol. Chem. 259: 9840-9846.

Schillace, R.V. and Scott, J.D. 1999. Association of the type 1 protein phosphatase PP1 with the A-kinase anchoring protein AKAP220. Curr. Biol. 9: 321-324.

Schmidt, P.H., Dransfield, D.T., Claudio, J.O., Hawley, R.G., Trotter, K.W., Milgram, S.L., and Goldenring, J.R. 1999. AKAP350: A multiply spliced A-kinase anchoring protein associated with centrosomes. J. Biol. Chem. 274: 3055-3066.

Scott, J.D. 1991. Cyclic nucleotide-dependent protein kinases. Pharmacol. Ther. 50: 123-145.

Scott, J.D., Zoller, M.J., Glaccum, M.B., Uhler, M.D., Helfman, D.M., McKnight, G.S., and Krebs, E.G. 1987. The molecular cloning of a type II regulatory subunit of the cAMP-dependent protein kinase from rat skeletal muscle and mouse brain. Proc. Nat1. Acad. Sci. 84: 5192-5196.

Sheng, M. and Kim, M.J. 2002. Postsynaptic signaling and plasticity mechanisms. Science 298: 776-780.

Skalhegg, B.S. and Tasken, K. 2000. Specificity in the cAMP/ PKA signaling pathway. Differential expression, regulation, and subcellular localization of subunits of PKA. Front. Biosci. 5: 678-693.

Smith, F.D. and Scott, J.D. 2002. Signaling complexes: Junctions on the intracellular information super highway. Curr. Biol. 12: $32-40$.

Soderling, S.H., Binns, K.L., Wayman, G.A., Davee, S.M., Ong, S.H., Pawson, T., and Scott, J.D. 2002. The WRP component of the WAVE-1 complex attenuates Rac-mediated signalling. Nat. Cell Biol. 4: 970-975.

Soderling, S.H., Langeberg, L.K., Soderling, J.A., Davee, S.M., Simerly, R., Raber, J., and Scott, J.D. 2003. Loss of WAVE-1 causes sensorimotor retardation and reduced learning and memory in mice. Proc. Natl. Acad. Sci. 100: 17231728.

Steen, R.L., Martins, S.B., Tasken, K., and Collas, P. 2000. Recruitment of protein phosphatase 1 to the nuclear envelope by A-kinase anchoring protein AKAP149 is a prerequisite for nuclear lamina assembly. J. Cell Biol. 150: 1251-1262.

Sudol, M. and Hunter, T. 2000. NeW wrinkles for an old domain. Cell 103: 1001-1004.

Suetsugu, S., Miki, H., and Takenawa, T. 1999. Identification of two human WAVE/SCAR homologs as general actin regulatory molecules which associate with the Arp2/3 complex. Biochem. Biophys. Res. Commun. 260: 296-302.

Sutherland, E.W. 1972. Studies on the mechanism of hormone action. Science 171: 401-408.

Takahashi, M., Shibata, H., Shimakawa, M., Miyamoto, M., Mukai, H., and Ono, Y. 1999. Characterization of a novel giant scaffolding protein, CG-NAP, that anchors multiple signaling enzymes to centrosome and the golgi apparatus. J. Biol. Chem. 274: 17267-17274.

Takahashi, M., Mukai, H., Oishi, K., Isagawa, T., and Ono, Y. 2000. Association of immature hypophosphorylated protein kinase $\mathrm{C}$ epsilon with an anchoring protein CG-NAP. J. Biol. Chem. 275: 34592-34596.

Takahashi, M., Yamagiwa, A., Nishimura, T., Mukai, H., and Ono, Y. 2002. Centrosomal proteins CG-NAP and kendrin provide microtubule nucleation sites by anchoring $\gamma$-tubulin ring complex. Mol. Biol. Cell 13: 3235-3245.

Tang, W.-J. and Gilman, A.G. 1992. Adenylyl cyclases. Cell 70: 869-872.

Tanji, C., Yamamoto, H., Yorioka, N., Kohno, N., Kikuchi, K., and Kikuchi, A. 2002. A-kinase anchoring protein AKAP220 binds to glycogen synthase kinase- $3 \beta$ (GSK-3 $\beta$ ) and mediates protein kinase A-dependent inhibition of GSK-3ß. J. Biol. Chem. 277: 36955-36961.

Tasken, K.A., Collas, P., Kemmner, W.A., Witczak, O., Conti, M., and Tasken, K. 2001. Phosphodiesterase 4D and protein kinase a type II constitute a signaling unit in the centrosomal area. J. Biol. Chem. 276: 21999-22002.

Tavalin, S.J., Colledge, M., Hell, J.W., Langeberg, L.K., Huganir, R.L., and Scott, J.D. 2002. Regulation of GluR1 by the Akinase anchoring protein 79 (AKAP79) signaling complex shares properties with long-term depression. I. Neurosci. 22: 3044-3051.

Theurkauf, W.E. and Vallee, R.B. 1982. Molecular characterization of the cAMP-dependent protein kinase bound to microtubule-associated protein 2. J. Biol. Chem. 257:32843290.

Vijayaraghavan, S., Goueli, S.A., Davey, M.P., and Carr, D.W. 1997. Protein kinase A-anchoring inhibitor peptides arrest mammalian sperm motility. J. Biol. Chem. 272: 4747-4752.

Walsh, D.A., Perkins, J.P., and Krebs, E.G. 1968. An adenosine 3',5'-monophosphate-dependent protein kinase from rabbit skeletal muscle. J. Biol. Chem. 243: 3763-3765.

Wang, X., Herberg, F.W., Laue, M.M., Wullner, C., Hu, B., Petrasch-Parwez, E., and Kilimann, M.W. 2000. Neurobeachin: A protein kinase A-anchoring, beige/Chediak-higashi protein homolog implicated in neuronal membrane traffic. $J$. Neurosci. 20: 8551-8565.

Wang, X., Zhong, P., and Yan, Z. 2002. Dopamine D4 receptors modulate GABAergic signaling in pyramidal neurons of prefrontal cortex. J. Neurosci. 22: 9185-9193.

Wang, Y., Scott, J.D., McKnight, G.S., and Krebs, E.G. 1991. A constitutively active holoenzyme from the cAMP-dependent protein kinase. Proc. Natl. Acad. Sci. 88: 2446-2450.

Westphal, R.S., Tavalin, S.J., Lin, J.W., Alto, N.M., Fraser, I.D., Langeberg, L.K., Sheng, M., and Scott, J.D. 1999. Regulation of NMDA receptors by an associated phosphatase-kinase signaling complex. Science 285: 93-96.

Westphal, R.S., Soderling, S.H., Alto, N.M., Langeberg, L.K., and Scott, J.D. 2000. Scar/WAVE-1, a Wiskott-Aldrich syndrome protein, assembles an actin-associated multikinase scaffold. EMBO T. 19: 4589-4600.

Witczak, O., Skalhegg, B.S., Keryer, G., Bornens, M., Tasken, K., Jahnsen, T., and Orstavik, S. 1999. Cloning and characterization of a cDNA encoding an A-kinase anchoring protein located in the centrosome, AKAP450. EMBO J. 18: 18581868.

Zaccolo, M. and Pozzan, T. 2002. Discrete microdomains with high concentration of cAMP in stimulated rat neonatal cardiac myocytes. Science 295: 1711-1715. 


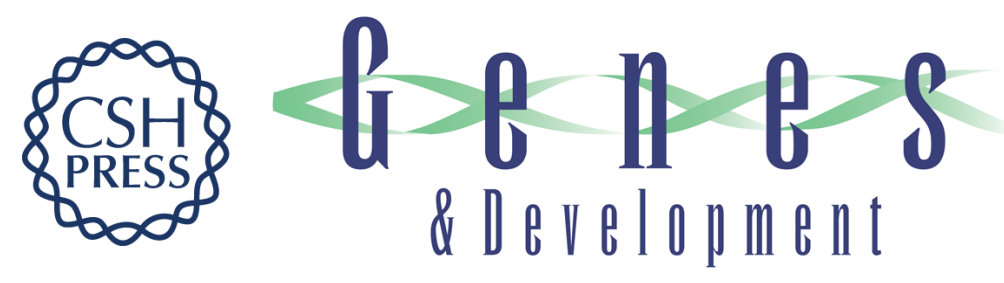

\section{A-kinase anchoring proteins and neuronal signaling mechanisms}

Graeme K. Carnegie and John D. Scott

Genes Dev. 2003, 17:

Access the most recent version at doi:10.1101/gad.1095803

References This article cites 143 articles, 87 of which can be accessed free at: http://genesdev.cshlp.org/content/17/13/1557.full.html\#ref-list-1

License

Email Alerting Receive free email alerts when new articles cite this article - sign up in the box at the top Service right corner of the article or click here.

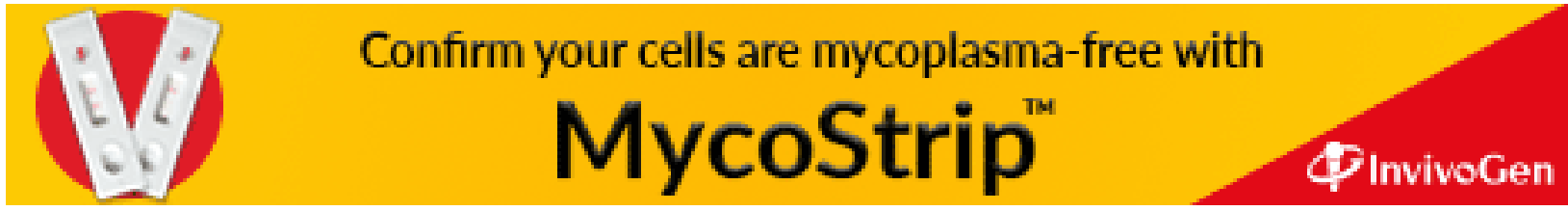

